DOI: $10.1515 /$ lpts-2016-0013

APPLIED PHYSICS

\title{
DETERMINATION OF CONTACT POTENTIAL DIFFERENCE BY THE KELVIN PROBE (PART I) I. BASIC PRINCIPLES OF MEASUREMENTS
}

\author{
O. Vilitis ${ }^{1}$, M. Rutkis ${ }^{1}$, J. Busenberg ${ }^{1}$, D. Merkulov ${ }^{2}$ \\ ${ }^{1}$ Institute of Solid State Physics, University of Latvia, Riga, LATVIA \\ ${ }^{2}$ Riga Technical University, Riga, LATVIA \\ e-mail: oskarsvil@gmail.com
}

\begin{abstract}
Determination of electric potential difference using the Kelvin probe, i.e. vibrating capacitor technique, is one of the most sensitive measuring procedures in surface physics. Periodic modulation of distance between electrodes leads to changes in capacitance, thereby causing current to flow through the external circuit. The procedure of contactless, non-destructive determination of contact potential difference between an electrically conductive vibrating reference electrode and an electrically conductive sample is based on precise control measurement of Kelvin current flowing through a capacitor. The present research is devoted to creation of a new low-cost miniaturised measurement system to determine potential difference in real time and at high measurement resolution. Furthermore, using the electrode of a reference probe, the Kelvin method leads to both the indirect measurement of an electronic work function, or a contact potential of sample, and of a surface potential for insulator type samples.

In the article, the first part of the research, i.e., the basic principles and prerequisites for establishment of such a measurement system are considered.
\end{abstract}

Keywords: Kelvin probe, contact potential difference, surface potential.

\section{INTRODUCTION}

At the end of 18th century, A. Volta conducted experiments on metal pairs and discovered the "contact electricity" that in modern language means the same as the contact potential difference (CPD) originating in the work function difference of two involved dissimilar electro-conducting materials. Volta revealed [1], if different metals are electrically connected in a sequential row and the temperature of all metals is equal, the potential difference between two external metals of this row does not depend on the other metal composition of this line. This potential difference is also known as the Volta potential. If the electrical contact is set between the outer end surfaces of metals in the row creating a closed loop, it follows from Volta law of serial contacts that the electric driving force in this circuit is equal to zero and the current 
does not flow unless the temperature of all metals composing the circuit is equal.

It is possible to use the diagrams of electron energy levels (see Fig. 1) to explain the occurrence of contact potential difference.

a)

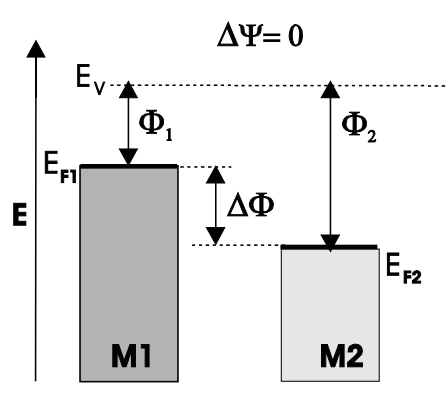

b)

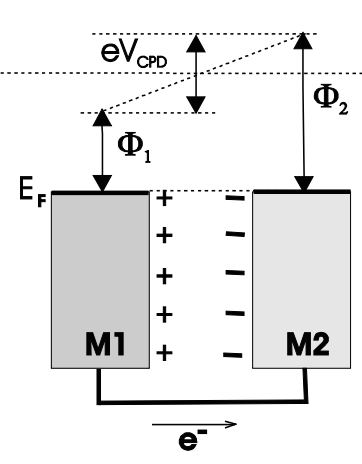

c)

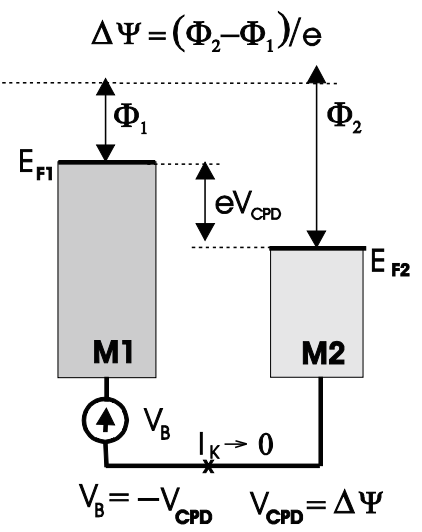

Fig. 1. Schematic representation of relationship between the contact potential difference $(\Delta \Psi)$ and the work functions $(\Phi)$.

The metals (Fig. 1a) before being connected were electrically neutral, and two metals having different work functions $\Phi_{1}$ and $\Phi_{2}$ shared the same local vacuum level $E_{v}$. The work function $\Phi$ is defined as the minimum work needed to extract electrons from the Fermi level of a solid carrying a net charge [2], [3]. Upon the short-circuiting, the electrons of metals (Fig. 1b) are flowing to a metal with higher work function until the uniform redistribution of electrons at the Fermi levels $E_{F I}$ and $E_{F 2}$ of both metals is reached. This leads to observation of Volta (or outer) potential difference $(\Delta \Psi)$, which is equivalent to a difference of work functions of two metals, and in our case:

$$
\Delta \Psi=\left(\Phi_{1}-\Phi_{2}\right) / e
$$

where $e$ is an elementary charge. Resulting voltage $V_{C P D}=\Delta \Psi$ compensates the work function difference by shifting the local vacuum level.

Figure 1(c) demonstrates that the shift of a local vacuum level can be compensated by an external "bucking voltage" (sometimes spelled "backing voltage"): $V_{B}=-V_{C P D}$. As the work function of metals is an intrinsic parameter, it remains constant after connection of two different metals [4], while the electrochemical potential of electrons within both phases becomes identical.

If the voltage $V_{B}$ is chosen such that the electric field is eliminated (the flat vacuum condition), the Volta (or outer) potential $V_{C P D}=\Delta \Psi=\left(\Phi_{1}-\Phi_{2}\right) / e$. Here, the potential $V_{C P D}$ in volts $(\mathrm{V})$ is equal to the energy $\left(\Phi_{1}-\Phi_{2}\right)$ in electron-volts $(\mathrm{eV})$ divided by an elementary charge (proton/electron charge) $e$.

Usually, the measuring device with the Kelvin probe uses metal (e.g. gold) as a probe, which is positioned within a short distance parallel to a flat sample material. 
If the sample is a conductor, the contact potential difference $\Delta \Psi$ can be evaluated similarly (see Eq. (1)). The Kelvin method is based on the Fermi level equilibrium model.

If the electrode of Kelvin probe is a metal, the electron's exchange energy at the Fermi level inside a solid determines the bulk contribution of the main work function defined as the minimum work needed to extract electrons from the Fermi level of solid carrying no net charge [4]. It is accepted that the electron is removed at the end position (vacuum level) just outside the sample. In this case, it can be assumed that the electrons inside a bulk of any conductor can move freely, the free electrons are located on the surface of solid, the work function is mainly the surface property and CPD value is determined by (1).

However, the CPD between a sample end and a probe (reference electrode) is dependent not only on the material work function, but also on the surface conditions, such as contamition and deposition of a monolayer. The work is required for electron to pass the barier at the surface of a solid, which is made of the dipole layer in case of conductors and of the band bending in case of semiconductors. This should be considered studying materials at normal pressure in moist air, and polycrystalline materials and insulators.

In semiconductors, the position of the Fermi level is between the valence and conduction bands, and additional work is required to move the electron from the Fermi level to the conduction band. The work required for the electron to pass the barier at the surface of the solid, which is the dipole layer in case of conductors and the band bending in case of semiconductors.

If the sample is metal or semiconductor, the charge may be formed not only at the sample surface, but also at the boundary between the sample and the conductive or semi-conductive substrate electrode. Part of the charge can move through the sample volume, where sample polarisation and charge catching by the traps are possible.

If the insulators are involved, the measured value apart from chemical potential difference of reference metal and sample substrate metal depends also on insulator boundary surfaces and thickness-dependent potential fall on the insulator.

In these cases and the ones above, a more common description of the work function is its presentation like the sum of chemical work to transfer the electron from just outside the sample to the Fermi level ( $\mu_{e}$, chemical potential) and the electrostatic work to move an electron trough the dipol layer $(\chi$, dipole or the surface potential), where $e$ is an elementary charge [4]:

$$
\Phi=-\mu_{e}+e \cdot \chi
$$

The Kelvin capacitor opposite materials (sample and gold-reference) are connected to each other through the outer circuit, so that the electrochemical potentials of electrons are in equilibrium. Therefore, the external potential difference at bucking voltage $V_{B}=0$ (Fig. 1b) is [5]:

$$
e\left(\Psi_{1}-\Psi_{2}\right)=\left(\mu_{e 1}-\mathrm{e} \chi_{1}\right)-\left(\mu_{e 2}-\mathrm{e} \chi_{2}\right)=\Phi_{2}-\Phi_{1}
$$


In respect to the measured values of Kelvin method, it is important to distinguish them when the difference of contact potentials or the difference of surface potentials is involved, and when the difference of work functions is concerned [5]. These conceptualisations initially apply to homogeneous surfaces.

As it has already been noted, if one electrode of the Kelvin condenser is connected to another, the electron diffussion begins from the electrode material with a higher Fermi level to the material with a lower one. At a time of level equalisation, the electrical potential on the electrode with a lower Fermi level is growing, and it is decreasing in the opposite case, thereby contact potential difference of the Kelvin condenser between electrodes is increasing. Without this outer Volta potential, the potential leap, i.e. the electrical field, arises directly at the place where both condenser electrodes are connected, which resists to the process of electron diffusion. If this inner contact potential difference reaches a certain value, the electron diffussion stops and Fermi levels of both electrode materials equalise. To let the electrical charge $e$ pass the phase boundary from the material "just inside the bulk" to one "outside the sample", it is necessary to do the work $e \chi$.

Thereby, the material electronic work function $\Phi$ is given by a sum of the chemical potential just inside the bulk $\mu_{e}$ and the electrical potential outside the sample $\chi$, as it has been mentioned (2). The surface potential is forming on the sample surface, but at the distance $l$ outside the surface it is gradually decreasing to zero, which is determined by the amount of free electrons compensating the charge carriers. The distance $l$ depends on the electrode material and on the presence of other surfaces and boundary phases, which could be located close enough to cause the mutual influence. Ignoring this fact, it can lead to errors when interpreting measurement results. The surface charge of metals is compensated by the free electrons outside the material surface at a distance of some atomic diameters, forming a few A thick dipole layer.

For semiconductors, the part of required charge for compensation is located at an extended boundary layer of the space charge zone. In this case, the Debye length $l=8_{D}$ can expand up to $1 \mu \mathrm{m}$ [5]. Therefore, it is possible to split the work function in a purely chemical work $\mu_{e}$ and a purely electric work e $\chi$.

On the other hand, it can also be divided: into the difference of conduction and valence bands $E_{C}-E_{F}$, the band bending $e V s$ and the electron affinity $\xi$ [5]:

$$
\Phi=\left(E_{C}-E_{\underline{F}}\right)-e V_{S}-\xi \text {. }
$$

If for semiconductors it is possible to interpret the measured value of two material contact potential differences as a difference of material two work functions, this interpretation is not applicable to insulators. For insulator samples without chemical potential difference of probe material and insulator grounding metal $\Delta \mu$, the measured potential difference $\Psi_{I S O L}-\Psi_{R E F}$ also comprises the potentials on the insulator boundary surfaces $\chi_{1}, \chi_{2}$ and thickness-dependent potential curve $V_{S}$ on the insulator [5].

$$
\begin{aligned}
& e\left(\Psi_{\mathrm{ISOL}}-\Psi_{R E F}\right)=\left(\mu_{e M}-\mathrm{e} \chi_{1}-\mathrm{e} \chi_{2}-V_{S}\right)-\left(\mu_{e R E F}-\mathrm{e} \chi_{R E F}\right)= \\
& =\Delta \mu-e\left(\chi_{1}+\chi_{2}+\chi_{R E F}\right)-e V_{S} .
\end{aligned}
$$


It is worthwhile to examine the validity of relation (1) for metal-semiconductor Kelvin probe arrangement in detail. In the isolated semiconductor, the surface band bending is determined by the free surface charge neutrality condition $Q_{s s}+Q_{s c}=0$, where $Q_{s s}$ is the net surface charge and $Q_{s c}$ is the net charge in the surface charge region (both per unit area). If the metal is connected to the back side of a semiconductor, the MIS structure (metal-isolator-semiconductor) is formed.

For example, in this case, it is possible to analyse whether the semiconductor band bending and, thus, its work function are changed. The appropriate charge neutrality condition becomes $Q_{m}+Q_{s s}+Q_{s c}=0$, where the effect of $Q_{m}$ (charge density on the metal + insulator surface) may be significant if the width of the capacitor gap is not much larger than the width of the surface depletion region [6]. Therefore, the potential energy drop across the capacitor gap may be modified to $\mathrm{eV}_{C P D}^{\prime}=\left(\Phi_{1}^{\prime}-\Phi_{2}\right)$ (where $\Phi_{1}^{\prime}$ is the modified work function of a semiconductor) instead of $\mathrm{eV}_{C P D}=$ $\left(\Phi_{1}-\Phi_{2}\right)$. However, the magnitude of external DC bias voltage $V_{B}$ required to discharge the capacitor remains equal and opposite to the real contact potential difference $V_{C P D}$ rather than to $V_{C P D}^{\prime}$. It happens because if the capacitor is discharged, $Q_{m}$ by definition is zero, the charge neutrality condition reduces to that of a free surface, and the semiconductor work function returns to its original value.

Nearly a hundred years passed since Volta had demonstrated the contact "electricity", while Lord Kelvin, 1898 [7], discovered possibility to measure the CPD also quantitatively. He used the condenser with plates of two various metals, as well as an electrometer, and it was for the first time when the direct measuring of CPD had been carried out compensating the measured potential difference with a variable outer voltage source (null-method). Zisman first applied this principle in the form of the vibrating capacitor in 1932 [8], which, in comparison with manual compensation arrangement, speeded up CPD measuring several times. And only then this method became widely applied in practice. In this case, the contact potential difference between the Kelvin probe and the conductive sample is equal to the applied compensation voltage.

Determination of the surface electric potential difference by the Kelvin probe, i.e. vibrating capacitor technique, is one of the most sensitive measuring procedures in surface physics. For instance, the Kelvin probe force microscopes and the scanning tunneling microscopes were modified to obtain a high-resolution data of electric surface potential distribution.

Due to its extremely high surface sensitivity, this method is used in many different areas of modern chemistry and physics to measure and analyse the surface characteristics of conductors, semiconductors, insulators, chemicals, biochemicals, photochemicals, chemical sensors, biosensors, biochemical microarrays, electronic image devices, micromachined devices, nanodevices, corroded materials, coatings, adsorbed materials, contaminated materials, oxides, thin films, liquid interfaces, self-assembling monolayers, and others [9]. The method is also applied to investigate semiconductor doping [10] and to study energy-level alignment of conjugated polymers deposited on various electrodes [11]. Besides, the further systems application was provided to measure and analyse different organic molecules and thin films [12]. The method is also used for high-resistivity non-polar and polar molecules deposited on both gold and ITO glass electrodes. The voltage drop over the capacitor formed by an organic layer and reference electrode is given [13]. 


\section{BASIC PRINCIPLES UNDERLYING THE MEASURING SYSTEM}

The Kelvin method is one of the most commonly used for CPD measuring. This contactless non-intrusive method is based on using the traditional Kelvin probe (see Fig. 2a) placed in plane-parallel to the stationary sample electrode at a distance $d_{0}$ shaping the simple two-plate capacitor.

To measure CPD, in accordance with the law of Volta's serial contacts, it is necessary to connect a variable voltage source $V_{B}$ and a series resistor $R_{I N}$ via an external circuit (see Fig. 2a). Due to difference in work functions of different electrode materials, CPD must be measured in an open circuit, i.e., using the dielectric such as vacuum or air between the surfaces of inner plates $V_{C P D}=\Delta \Psi$. To improve the resolution of a sample surface scanning, a small probe surface is required. The orientation of Kelvin probe surface area with respect to a sample surface is analogous to a parallel plate capacitor, whose capacitance $C$ is defined:

$$
C=\left(\varepsilon_{\mathrm{o}} \cdot \varepsilon_{r} \cdot \mathrm{A}\right) / d_{0},
$$

where $\varepsilon_{0}$ is a dielectric constant, $\mathrm{A}$ is an area of Kelvin probe and $d_{0}$ is a distance between plates. The dielectric constant $\varepsilon_{r}$ for measurements in air or vacuum is assumed to be 1 .

a)

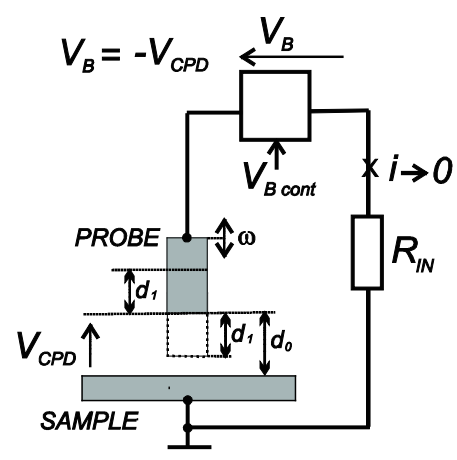

b)

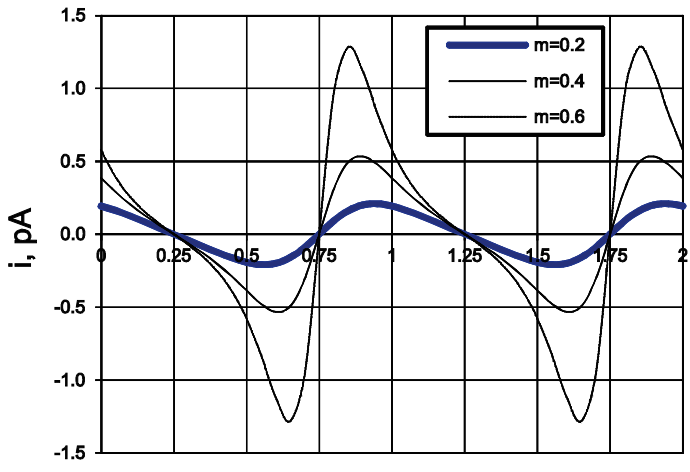

$\mathrm{t} / \mathrm{T}$

Fig. 2. Schematic of the Kelvin probe input stage: a) variable applied bucking potential $V_{B}$ source block with its control voltage $V_{B c o n}, i$ - the current in Kelvin probe outer circuit $R_{I N}$, $V_{C P B}$ - the contact potential difference between Kelvin condenser inner electrodes PROBE and SAMPLE, $d_{0}$ - the mean distance between the sample and the probe, $d_{1}$ - the amplitude of the probe vibration depending on time $t$ expressed in vibration periods. b) The wave form of current $i(t)$, see Eq. (11) for different values of modulation factor $m$. It illustrates the appearance of Kelvin probe signal oscillograms.

If the voltage $V_{C P D}$ caused by Kelvin condenser inner surface potentials is constant, the condenser charges at charge $Q$ :

$$
Q=C \cdot V_{C P D} .
$$


The Kelvin probe is stimulated to a sinusoidal vibration around the average distance $d_{0}$ between Kelvin probe electrode and the sample surface with amplitude $d_{1}\left(d_{1}<d_{0}\right)$ and frequency $\omega$ expressed in radians.

Kelvin probe location changes with time, hence:

$$
d(t)=d_{0}+d_{1} \cdot \sin (\omega t)
$$

Ratio $d_{1}$ to $d_{0}$ characterises the amplitude of current signal and is referred to the modulation factor $\mathrm{m}$ :

$$
m=d_{1} / d_{0}
$$

It follows from Eqs. (6), (7) that the charge $Q$ will change along with changes of Kelvin probe capacity resulting in change of current $i(t)$ in the outer circuit, which at the bucking voltage $V_{B}=0$ and $V_{C P D} \neq 0$ reproduces current:

$$
i(t)=d Q / d t=V_{C P D} \cdot d C / d t
$$

Substituting Eqs. (6)-(8) into Eq. (7), the current signal i(t) can be expressed as:

$$
i(t)=V_{C P D} \cdot \varepsilon_{0} \cdot \varepsilon_{r} \cdot \mathrm{A} \cdot[m \cdot \omega \cdot \cos (\omega t)] /\left[1+m \cdot \sin (\omega t)^{2}\right] .
$$

In the conventional nulling technique [14], the variable bucking potential $V_{B}$ is adjusted until the Kelvin current vanishes $i \rightarrow 0 . V_{B}$ is equal and opposite to $V_{C P D}$, the electric field between the Kelvin capacitor electrodes is compensated and the zero output signal is recorded, wherein the ac current in the Kelvin probe outer circuit drops to zero: $i(t)=\left(V_{C P D}+V_{B}\right) \cdot d C / d t=0$ if $V_{C P D}=-V_{B}$.

Determination of voltage $V_{C P D}$ caused by a contact potential difference on the vibrating electrode of capacitor in the systems with the Kelvin probe is asociated with involving of the compensating voltage $V_{B}$ in the capacitor external circuit, at which the Kelvin current $i(t)$ disappears. In this case, the absolute value of signal $V_{C P D}$ comes into balance with a value of voltage $V_{B}$ and $V_{C P D}$ polarity is opposite to polarity $V_{B}$. However, the exact measurement of the equilibrium point $V_{C P D}$ is getting more complex by the fact that at this area the signal-to-noise ratio reaches minimum by $i(t) \rightarrow 0$, and the noise creates the biasing voltage, thereby causing measurement errors. Therefore, the present conventional $V_{C P D}$ measuring systems use the "offnull" algorithm, where the Kelvin probe signal is measured at two or more values of $V_{B}$, for instance, at high signal levels, and the balance point is obtained by extrapolation.

However, this accurate nulling technique also has several disadvantages, as we have already pointed out above. Thus, the statistical linear correlation-regression analysis, despite its high complexity in case of an area scan with a few hundred measurement points, first of all requires completing a set of all measurements. Thus, the online monitoring of the contact potential difference is not possible and the result of the measurement can be analysed only after the experiment is finished. Furthermore, the above-mentioned modified off-null technique implementation is generally associated with a need of a PC with pre-installed extensive software and use of the 
external data acquisition digital control unit with a host PC data acquisition system housed in the PC system, which not only increases the extent and the weight of the measuring equipment but also raises production costs and, therefore, limits the wider use of the Kelvin probe.

We have indicated a new and simple way that allows determining the contact potential difference by entering the composite and time-varying bucking voltage in the Kelvin probe measuring circuit.

The results of experimental measurement system test for determination of the contact surface potential difference in the range of $+10,000 \mathrm{~V}$ up to $-10.000 \mathrm{~V}$ have shown the stable measurement resolution in the range of $\pm(1-2 \mathrm{mV}$ ) (See Part 2 of this article in one of the upcoming journals).

\section{CONCLUSIONS}

The basic characteristics and principles for determination of contact potential difference using the Kelvin probe and the preconditions for development of such a measurement system have been considered, namely:

- under the following conditions, the measured value is the difference between outer potentials of two materials of Kelvin capacitor electrodes. If these materials are metals or semiconductors, the measured value can be interpreted as a difference between the work functions of these materials. The charge can be formed not only at the sample surface, but also at the boundary between the sample and the conductive or semi-conductive substrate electrode. Part of the charge can move through the sample volume, where sample polarization and charge catching by the traps is possible. If the insulators or semiconductors with low electrical conductivity are involved, the measured value apart from chemical potential difference of reference metal and sample substrate metal also depends on insulator boundary surfaces and thickness-dependent potential fall on the insulator.

- the main principles and conditions, underlying the measuring systems and assessment of their effectiveness.

\section{REFERENCES}

1. Volta, A. (1800). On the electricity exited by the mere contact of conducting substances of different kinds. Philos. Mag. 7, 298-311.

2. Maljusch, A., Henry, J.B., Tymoczko, J., Bondarenka, A.S., and Schuhmann, W. (2013). Towards linking basic surface properties with electrocatalytic activity. Electronic Supplementary Material (ES) for RSC Advances, 1-3.

3. McNaught, A.D., and Wilkinson, A. (1997). IUPAC. Compendiom of Chemical Terminology. Oxford: Blackwell Scientific Publications.

4. Maljusch, A. (2012). Integrated scanning Kelvin probe - scanning electrochemical microscopy system: design, development and applications. Diss., 1-245.

5. Ostrick, B. (2000). Die Untersuchung der Karbonat - Kohlendioxid - Wechselwirkung im Feuchtefilm der Oberfläche. Diss., 1-131. 
6. Kronik, L., and Shapira, Y. (1999). Surface photovoltage phenomena: theory, experiment, and applications Surf. Sci.e Rep. 37, 1-206.

7. Thomson, W. (later Lord Kelvin) (1898). Contact electricity of metals. Philos. Mag. 46, $82-120$.

8. Zisman, W.A. (1932). Rev Sci. Instrum. 3. 367-370.

9. Thompson, M., and Cheran, L.E. (2006). Scanning Kelvin microprobe system and process for analyzing a surface. US Patent Nr. US 7084661 B2.

10. Filipavičivs, V., Gaidys, R., Matulaitis, V.A., Petrauskas, G., Sakalas, A., and Sakalauskas, A. (1987). Investigation of the surface states in heavily doped GaAs by Kelvin probe. Phys. Stat. Sol. 99, 543-547.

11. Lange, I., Blakeslay, J.C., Frisch, J., Vollmer, A., Koch, N., and Neher, D. (2011). Band bending in conjugated polymer layers. Phys. Rev. Letters 106, 216402-1-216402-4.

12. Vilitis, O., Fonavs, E., and Muzikante, I. (2001). A system for measuring surface potential by the Kelvin-Zisman vibrating capacitor probe. Latv. J. Phys. Techn. Sci. 5, 38-56.

13. Pfeiffer, M., and Leo, K. (1996). Fermi level determination in organoc thin films by the Kelvin probe method. J. Appl Phys. 80 (12), 6880-6883.

14. Ritty, B., Wahtel, Ott, F., Manquenouille, R., and Donnet, J.B. (1980). New application of the Kelvin method involving the scanning of the bucking voltage. Rev. Sci. Instrum. $51(10), 1421-1423$.

\title{
KONTAKTPOTENCIĀLU STARPĪBAS NOTEIKŠANA AR KELVINA ZONDI (I DAL,A) 1. MĒRIIŠANAS PAMATPRINCIPI
}

\author{
O. Vilītis, M. Rutkis, J. Busenbergs, D. Merkulovs
}

\section{Kopsavilkums}

Kontaktpotenciālu starpības izraisītā sprieguma $V_{C P D}$ noteikšana uz vibrējoša kondensatora elektrodiem sistēmās ar Kelvina zondi ir saistīta ar tāda kompensējoša sprieguma $V_{B}$ iesaistīšanu kondensatora ārējā k,ēēe, pie kura izzūd Kelvina strāva $i(t)$. Šajā gadījumā signāla $V_{C P D}$ absolūtais lielums nonāk līdzsvarā ar sprieguma $V_{B}$ lielumu un tā polaritāte ir pretēja $V_{B}$ polaritātei. Taču precīzu $V_{C P D}$ mērīšanu līdzsvara punktā sarežǵī tas, ka, ja $i(t) \rightarrow 0$, signāla un trokšņa attiecība sasniedz minimumu, un trokšni rada nobīdes spriegumu un līdz ar to kḷūdas mērījumā.

Tādēl patlaban konvencionālajās $V_{C P D}$ mērīšanas sistēmās izmanto t.s. 'offnull' algoritmu, pie kura Kelvina zondes signālu vispirms mēra, piemēram, pie divām vai vairākām augstākām signāla $V_{B}$ vērtībām un pēc tam atrod minēto līdzsvara punktu ekstrapolācijas ceḷā.

Taču arī šādam precīzam nullēšanas paņēmienam piemīt daži trūkumi. Tā, ja skenējamā parauga apgabalā tiek ietverti vairāki simti mērīšanas punkti, statistiskā korelācijas un regresijas analīze, neraugoties uz tās augsto sarežǵîtīibas pakāpi, prasa, lai vispirms būtu veikts pilns visu mērījumu kopums. Tādējādi, nav iespējama 
operatīva kontaktpotenciālu starpības monitorēšana, jo mērījumu rezultātus var analizēt tikai pēc eksperimenta pabeigšanas. Bez tam, iepriekšminētā modificētā 'off-null' paṇēmiena realizācija parasti ir saistīta ar nepieciešamību izmantot datoru ar tajā iepriekš instalētu plašu programmatūras nodrošinājumu un ārējo datu ieguves digitālo vadības bloku ar hostdatorā izvietoto datu ieguves sistēmu. Tas ne vien palielina mērīšanas aprīkojuma apjomu un svaru, bet arī paaugstina ražošanas izmaksu un, līdz ar to, ierobežo Kelvina zondes plašāku pielietojumu.

Esam norādījuši jaunu un vienkāršu veidu, kas ḷauj nepārtraukti noteikt kontakta potenciālu diferenci $V_{C P D}$, regulāri ievadot Kelvina zondes mērīšanas ķēdē kompozītu un laikā mainīgu pretspriegumu $V_{B}$ (skatīt š̀i raksta otro daḷu kādā no turpmākajiem žurnāliem). Eksperimentālie mērī̌sanas sistēmas testa rezultāti pa noteiktu kontakta virsmu potenciālu starpības robežās no $+10,000 \mathrm{~V}$ līdz $-10.000 \mathrm{~V}$ ir parādījuši stabilu $\pm(1-2 \mathrm{mV})$ mērījumu izšķirtspēju.

18.01.2016. 